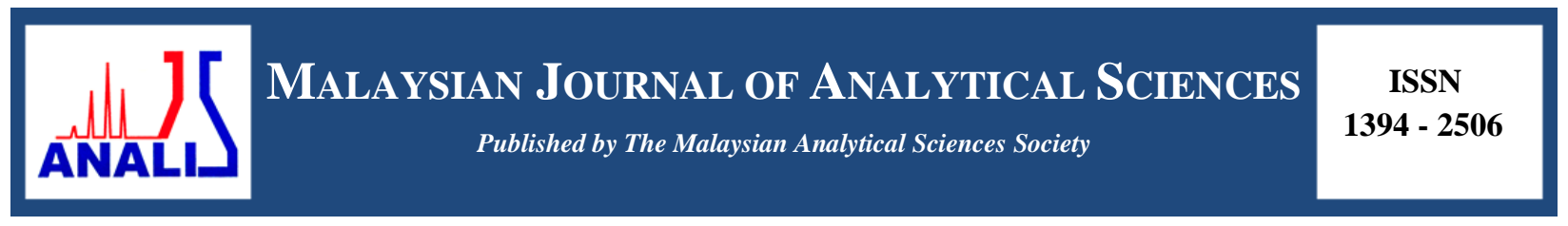

\title{
EFFECT OF EDIBLE LIPID-CHITOSAN FILM FORMING DISPERSION ON POSTHARVEST LIFE OF GUAVA STORED AT CHILLED TEMPERATURE
}

\author{
(Kesan Serakan Filem Lipid-Kitosan Ke Atas Jangka Hayat Jambu yang Disimpan Pada Suhu \\ Sejuk)
}

\author{
Nurul Adilla M. Loai, Halimahton Zahrah Mohamed Som*, Zaibunnisa Abdul Haiyee \\ Faculty of Applied Sciences, \\ Universiti Teknologi MARA, 40450 Shah Alam, Selangor, Malaysia \\ *Corresponding author: halimah@salam.uitm.edu.my
}

Received: 24 February 2015; Accepted: 27 October 2015

\begin{abstract}
An edible lipid-chitosan film forming dispersion (FFD) was developed to delay ripening of guava. Four percent (v/v) of palm stearin (PS) and palm kernel olein (PKOo) in ratios of 0:100, 25:75, 50:50, 75:25 and 100:0 were added to a chitosan solution base and applied on guava by dipping technique. Surface appearance, weight loss, firmness, carbon dioxide, oxygen and ethylene concentrations were evaluated every 3 days during 31 days of storage at chilled temperature $\left(5 \pm 2{ }^{\circ} \mathrm{C}\right)$. An application of FFD on guava significantly $(\mathrm{p}<0.05)$ delayed chilling injury, reduced weight loss, maintained firmness, slowed down respiration and ethylene production as compared to uncoated guavas. PS:PKOo (75:25) coating was able to form compatible blends and showed good moisture and gas barrier properties when applied on guava surface, resulting in increased postharvest life of guava.
\end{abstract}

Keywords: guava, film forming dispersion, chitosan, palm stearin, palm kernel olein

\section{Abstrak}

Serakan filem lipid-kitosan yang boleh dimakan telah dihasilkan untuk melambatkan proses jambu untuk ranum. Empat peratus (v/v) stearin sawit dan olein isirong sawit dengan nisbah 0:100, 25:75, 50:50, 75:25 and 100:0 telah ditambah ke dalam larutan kitosan dan diaplikasikan ke atas jambu dengan menggunakan teknik celupan. Permukaan buah, kehilangan berat, kekerasan, kepekatan gas karbon dioksida, oksigen dan etilena telah dikaji setiap 3 hari sepanjang 31 hari penyimpanan di dalam suhu sejuk $\left(5 \pm 2{ }^{\circ} \mathrm{C}\right)$. Penggunaan salutan ke atas jambu telah melambatkan kerosakan buah, mengurangkan kehilangan berat, mengekalkan kekerasan, melambatkan proses respirasi dan penghasilan etilena jika dibandigkan dengan jambu yang tidak disalut. Salutan PS:PKOo (75:25) telah menghasilkan campuran yang sesuai dan menunjukkan sifat-sifat penghalang air dan gas yang baik apabila diaplikasikan ke atas permukaan jambu dan telah meningkatkan jangka hayat jambu.

Kata kunci: jambu, serakan lapisan filem, kitosan, stearin sawit, olein isirong sawit

\section{Introduction}

Guava is an excellent source of vitamin $\mathrm{C}$ and is grown for both the domestic and exports markets. However, guava ripens rapidly during transportation and storage, thus often requiring rapid shipment in order to prolong postharvest life and decrease its respiration rate. Many postharvest diseases such as anthracnose, mucor rot and aspergillus rot can also limit the commercialisation of guava. Although refrigeration can increase the shelf life of guava, it adds cost and may cause chilling injury. Thus, coating the fresh fruit appears to be a cheaper alternative to preserve guava. 
Materials that can be used to make edible coating includes polysaccharides [1], proteins [2] and lipids [3], or a combination of these materials [4]. Most hydrophilic films are excellent gas, aroma and lipid barriers with good mechanical properties, while hydrophobic films have high moisture resistance with poor mechanical properties. Improved film or coating performance can be obtained when hydrophilic and hydrophobic compounds are mixed.

Chitosan as a coating material has good antimicrobial [4] and gas barrier properties [5] with its tough and flexible film [6]. To date, there is no research data on the study of functional properties of chitosan based dispersion incorporated with palm stearin and palm kernel olein (PKOo). It can thus be combining with palm stearin and PKOo to provide moisture barrier properties, as PKOo has limited application because of excessive foaming due to medium-short chain fatty acids [7]. Results obtained from this study can be used to assess the potential of lipidchitosan coating, besides diversifying the use of palm stearin and PKOo.

\section{Chemicals and raw materials}

\section{Materials and Methods}

Raw materials used were guava, chitosan, palm kernel olein and palm stearin. Refined, bleached and deodorised medium-hard palm stearin (IV: 33, SMP: 54) and palm kernel olein (IV: 24, SMP: 25) were obtained from Cargill Specialty Fats (M) Sdn. Bhd, Pelabuhan Klang, Malaysia. Guavas (Psidium guajava L.) at maturity index 2 were obtained from FAMA Chui Chak, Bidor, Perak, Malaysia. High molecular weight chitosan, with a deacetylation degree of $85 \%$ was purchased from Saintifik Zener Sdn. Bhd, Kuala Lumpur, Malaysia. Glacial acetic acid (99.5 $\%$ ), glycerol and Tween 80 were supplied by Merck Sdn Bhd, Petaling Jaya, Selangor, Malaysia.

\section{Preparation of film forming dispersion (FFD)}

An amount $3 \mathrm{~g}$ of chitosan was dispersed in an aqueous solution of glacial acetic acid $(0.75 \% \mathrm{v} / \mathrm{v})$, at $40{ }^{\circ} \mathrm{C}$. Tween 80 at $0.1 \%(\mathrm{v} / \mathrm{v})$ and $0.5 \%$ of glycerol were added and the FFD was shaken by using an orbital shaker at $350 \mathrm{rpm}$, $65{ }^{\circ} \mathrm{C}$. After 8 hours, palm stearin and palm kernel olein were added at $4 \%(\mathrm{v} / \mathrm{v})$ in ratios of 0:100, 25:75, 50:50, 75:25 and 100:0 to the chitosan solution. These mixtures were then emulsified at room temperature using a high speed homogeniser at $13500 \mathrm{rpm}$ for 4 minutes [8].

\section{Coating application}

Guavas of uniform size, shape and colour and without any signs of mechanical damage or fungal decay were selected. The fruits were washed and immersed in $10 \mathrm{mg} / \mathrm{L}$ of sodium hypochlorite solution for 5 minutes and then drained prior to coating. The fruits were dipped in the FFD for 15 seconds [9] while control samples were dipped in distilled water. Fruits were allowed to dry at ambient temperature on trays, and were stored at chilled temperature (5 $\pm 2^{\circ} \mathrm{C}$ ) and $80-95 \%$ relative humidity for 31 days. Temperature and relative humidity were measured by using a Temperature and RH logger (HOBO U12 - O13) [10].

\section{Physicochemical analyses}

Physicochemical analyses of guava were performed at 1, 4, 7, 10, 13, 16, 19, 22, 25, 28, and 31 days of storage.

\section{Determination of surface appearance}

Guavas samples were assessed by visual inspection on overall appearance, colour changes and acceptability at 1 , $4,7,10,13,16,19,22,25,28$, and 31 days of storage. Pictures of guavas were captured by using a digital camera (Canon IXUS HS115). Guava that showed any sign of fungal development was considered decayed [11].

\section{Determination of weight loss}

Weight loss was determined by weighing the samples on a laboratory digital balance (A \& D HF-300, Japan) after air-drying the FFD and thereafter at 1, 4, 7, 10, 13, 16, 19, 22, 25, 28, and 31 days of storage. Results were expressed as percentage loss of moisture based on the original mass [12].

\section{Determination of firmness retention}

Firmness of guava was determined by using a TA-XT2i Texture Analyzer (Stable Microsystems, Surrey, UK) equipped with a compression cell of $10 \mathrm{~kg}$ and a cylindrical and flat acrylic probe of $1 \mathrm{~cm}$ in diameter, $10 \mathrm{~mm} / \mathrm{s}$ crosshead speed, a $1 \mathrm{~N}$ force and a $75 \%$ strain to penetrate the fruit. Determination was performed at three different 
parts of guavas. Results were expressed as percentage of firmness retention (compression force at storage time was compared to force on day 1) [13].

\section{Determination of gas concentrations}

Carbon dioxide and ethylene concentrations were measured by enclosing each fruit in a $0.5 \mathrm{~L}$ plastic jar, hermetically sealed with a rubber stopper for one hour. One milliliter of the atmosphere in the plastic jar was withdrawn into a gas tight syringe. Carbon dioxide and ethylene concentrations were quantified using a Gas Chromatograph (Agilent 78990A) equipped with Thermal Conductivity Detector (TCD) and Flame Ionization Detector (FID), respectively. Column and detector temperatures were $55{ }^{\circ} \mathrm{C}$ and $180{ }^{\circ} \mathrm{C}$, respectively. The carrier gas was helium at a flow rate of $50 \mathrm{ml} / \mathrm{min}$. Results from the means of triplicate determinations were expressed in ppm (10). Oxygen concentration was analysed in the same headspace gas by using a carbon dioxide and oxygen analyzer (Mocon Pac Check 200). Results from the means of triplicate determinations were expressed as percentage of oxygen [14].

\section{Statistical analysis}

SPSS for Windows Evaluation (version 15.0) was used for all statistical analyses. Analysis of variance and Duncan multiple comparisons were performed at $5 \%$ confidence level.

\section{Surface appearance}

\section{Results and Discussion}

The overall acceptability of fruit was evaluated based on the appearance of fruit skin. The results obtained on the visual appearance of guavas are shown in Figure 1. The uncoated guava showed sign of chilling disorder at day 13 with the chilling injury becoming more prominent as storage progressed. Lipid-chitosan coating (PS:PKOo 75:25) delayed the chilling injury of guava by shifting the chilling disorder to day 22 of storage. The coating delayed disease development and retarded the ripening process. The intensification of chilling injury during storage of guava was also observed by Gonzalez-Aguilar et al [15]. Meanwhile, Vargas et al [9] reported that surface moisture loss could be responsible for the darker colour of fruits's skin.

\begin{tabular}{|c|c|c|c|c|c|c|c|}
\hline & Control & Chitosan & $\begin{array}{c}\text { PS:PKOo } \\
\text { (0:100) }\end{array}$ & $\begin{array}{c}\text { PS:PKOo } \\
\text { (25:75) }\end{array}$ & $\begin{array}{c}\text { PS:PKOo } \\
\text { (50:50) }\end{array}$ & $\begin{array}{c}\text { PS:PKOo } \\
\text { (75:25) }\end{array}$ & $\begin{array}{c}\text { PS:PKOo } \\
\text { (100:0) }\end{array}$ \\
\hline Day 1 & & & & & & & \\
\hline Day 4 & & & & & & & \\
\hline Day 7 & & & & & & & \\
\hline Day 10 & & & & & & & \\
\hline
\end{tabular}

Figure 1. Appearance of seedless guavas stored at chilled temperature 


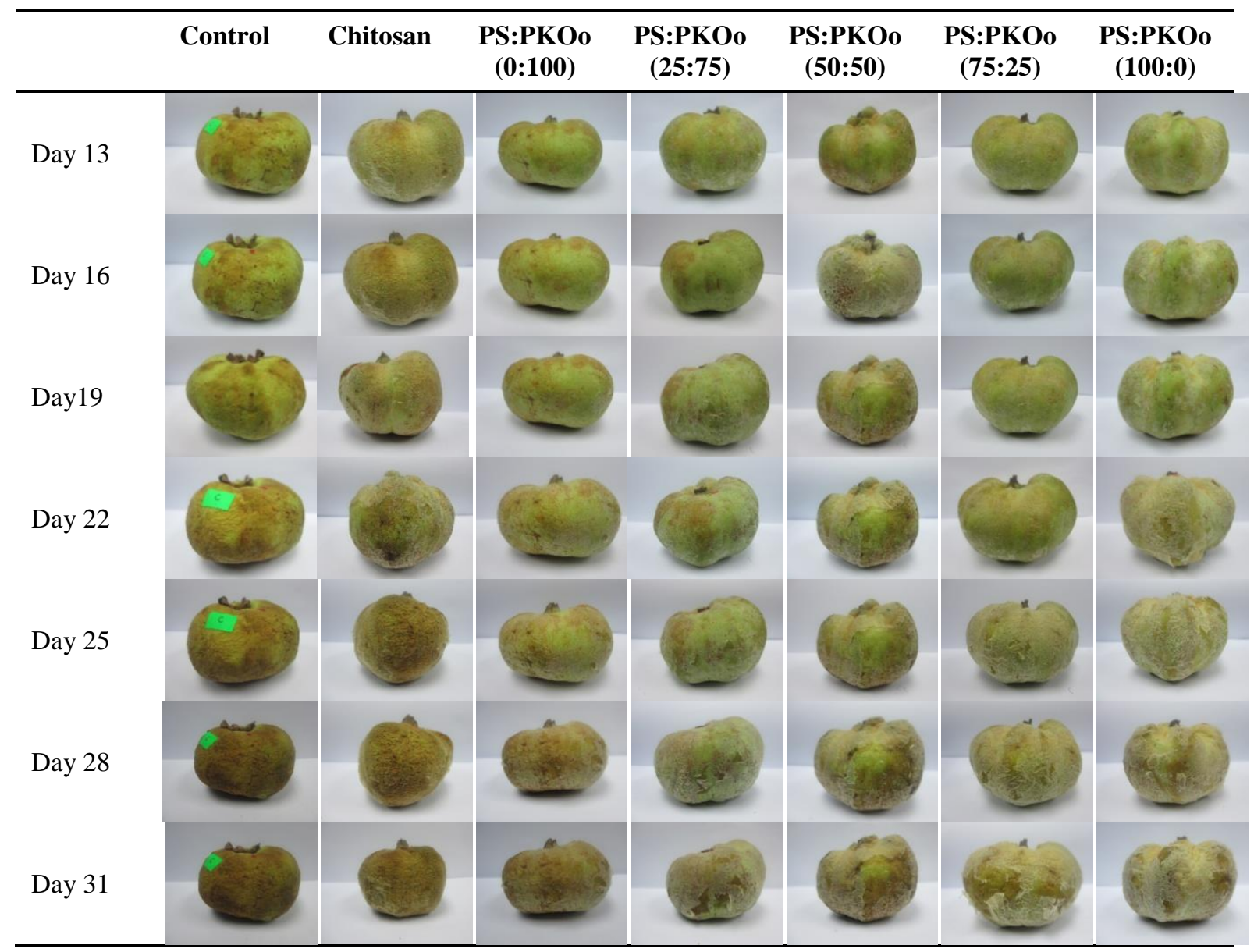

Figure 1 (cont'd). Appearance of seedless guavas stored at chilled temperature

\section{Weight loss}

Figure 2 shows the increases in weight loss of both coated and uncoated guavas. The results obtained showed that chitosan coating significantly reduced the weight loss of guava. Similar results were also observed with chitosan coating on sliced mango fruit at chilled temperature [5]. In this study, lipid-chitosan coatings exhibited smaller weight loss as compared to chitosan coating, with PS:PKOo (75:25) coated guava showing the lowest percentage of weight loss. This phenomenon happened probably due to the optimum interaction of PS and PKOo with chitosan during the drying process.

In this study, lipid-chitosan coatings showed good moisture barrier properties due to the combination of PS and PKOo. The lipids gave better protection on moisture loss of the seedless guava hence slowing down the weight loss of fruits. These results agreed with the findings of other researchers who reported that coatings made from lipids have good water vapour barrier properties. This is because lipids are not miscible with water, hence water is retained and shrinkage of fruits is prevented [16].

\section{Firmness retention}

Results on firmness retention of guavas are shown in Figure 3. Firmness of guava coated with chitosan coating decreased slower compared to uncoated guava because the chitosan coating provided the barrier to gases in the fruit. Lipid-chitosan coating could retain the firmness of guava better than chitosan coating alone, because the incorporation of lipid into chitosan coating was able to provide both moisture and gas barrier properties. PSPKOo 
(75:25) coating appeared to be the best formulation in preventing the loss of water vapour and maintained the firmness of seedless guavas. Yaman and Bayoundurh [17] reported that the decrease of oxygen and increase in carbon dioxide concentrations reduced the activity of enzyme that is responsible for texture loss, hence allowing the retention of fruit firmness.

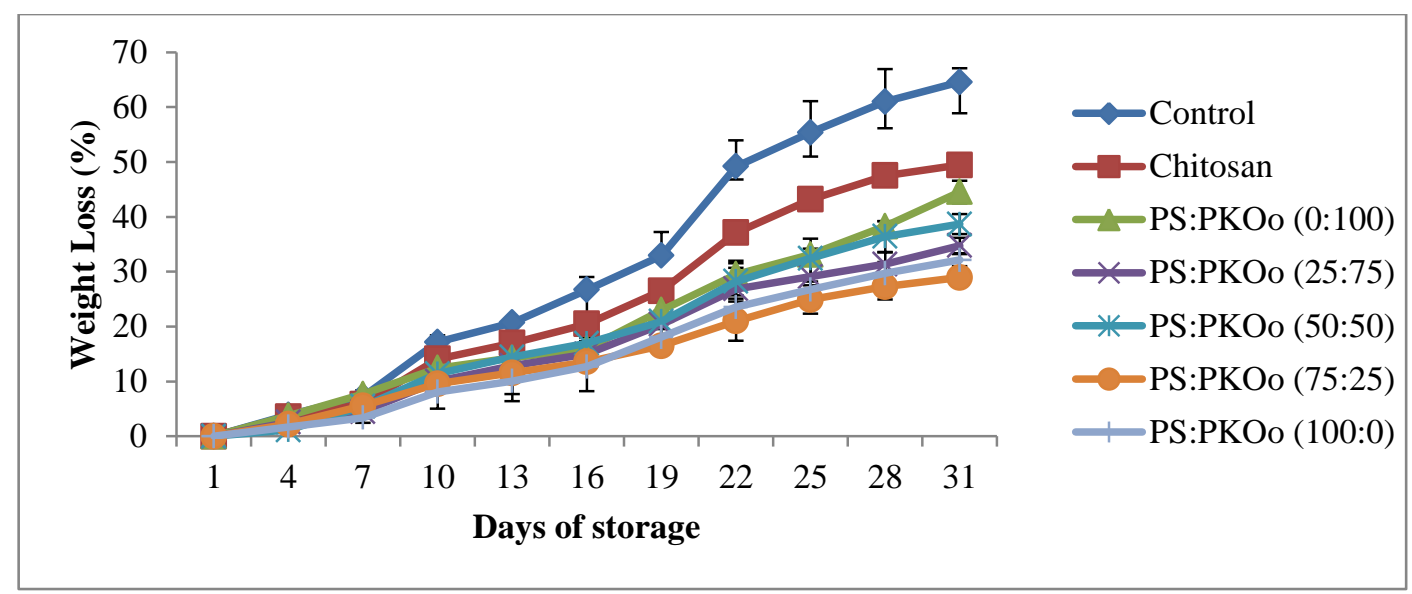

Figure 2. Weight loss of seedless guavas during storage at chilled temperature

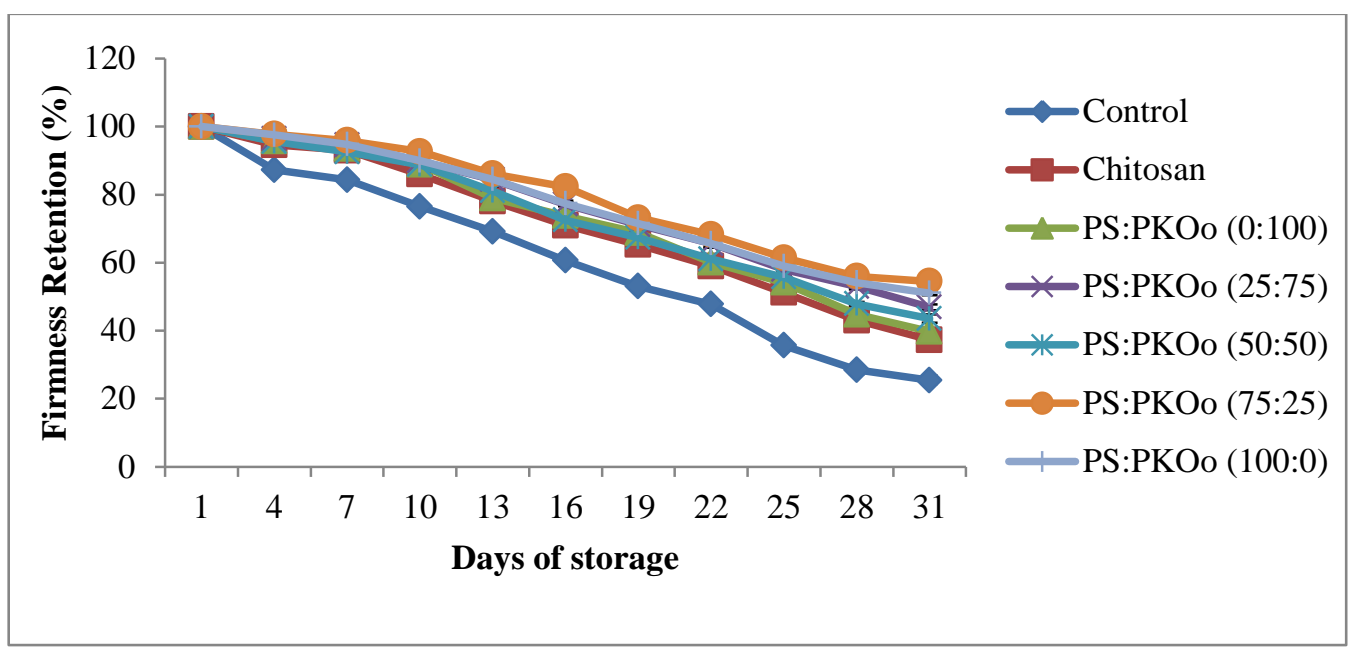

Figure 3. Firmness retention of seedless guavas during storage at chilled temperature

\section{Ethylene concentration}

Figure 4 shows the ethylene production of guavas during storage at chilled temperature. Chilled storage is one of the methods used to delay fruit maturation by reducing respiration and synthesis of ethylene, which cause maturation. The ethylene production during ripening of guava exhibited a typical climacteric pattern of respiration for climacteric fruits. The uncoated guava reached the climacteric peak at day 13 while chitosan coated guava reached the climacteric peak after day 16. 


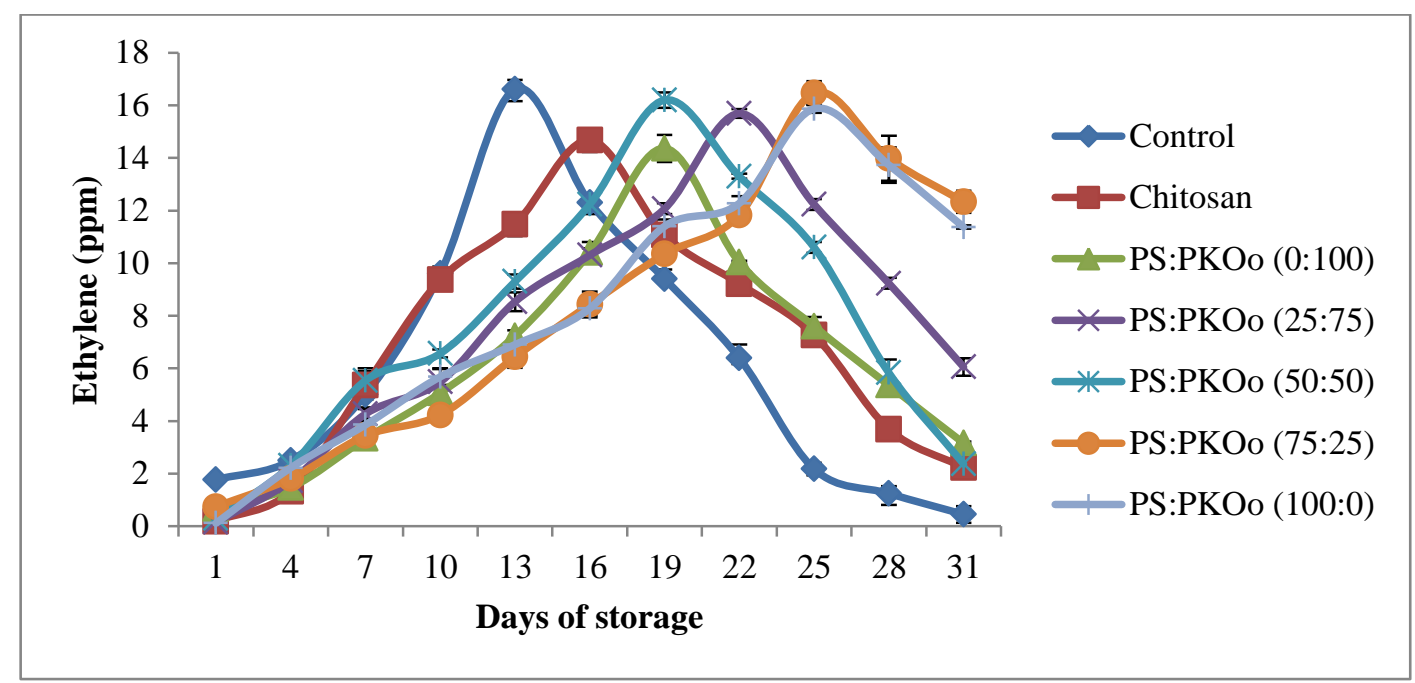

Figure 4. Ethylene concentration of seedless guavas during storage at chilled temperature

The amount of ethylene release for guavas that were coated with chitosan coating, PS:PKOo (0:100), PS:PKOo (25:75), PS:PKOo (50:50), PS:PKOo (75:25) and PS:PKOo (100:0) increased with storage time and reached the highest values of $14.67 \mathrm{ppm}, 14.36 \mathrm{ppm}, 15.69 \mathrm{ppm}, 16.20 \mathrm{ppm}, 16.47 \mathrm{ppm}$ and $15.87 \mathrm{ppm}$, respectively. Ethylene production decreased gradually after reaching the climacteric peaks. The decrease in ethylene concentration was probably due to the emergence of chilling injury on the fruit surface. Guavas that were coated with PS:PKOo (75:25) and PS:PKOo (100:0) shifted the climacteric peak of uncoated guava from day 13 to day 25. The results showed that both coatings showed greater gas barrier properties compared to the other coatings.

\section{Carbon dioxide and oxygen concentrations}

Figure 5 presents the concentration of carbon dioxide throughout chilled storage of guava. Coated guavas showed significantly lower amount of carbon dioxide than the uncoated guavas during chilled storage.

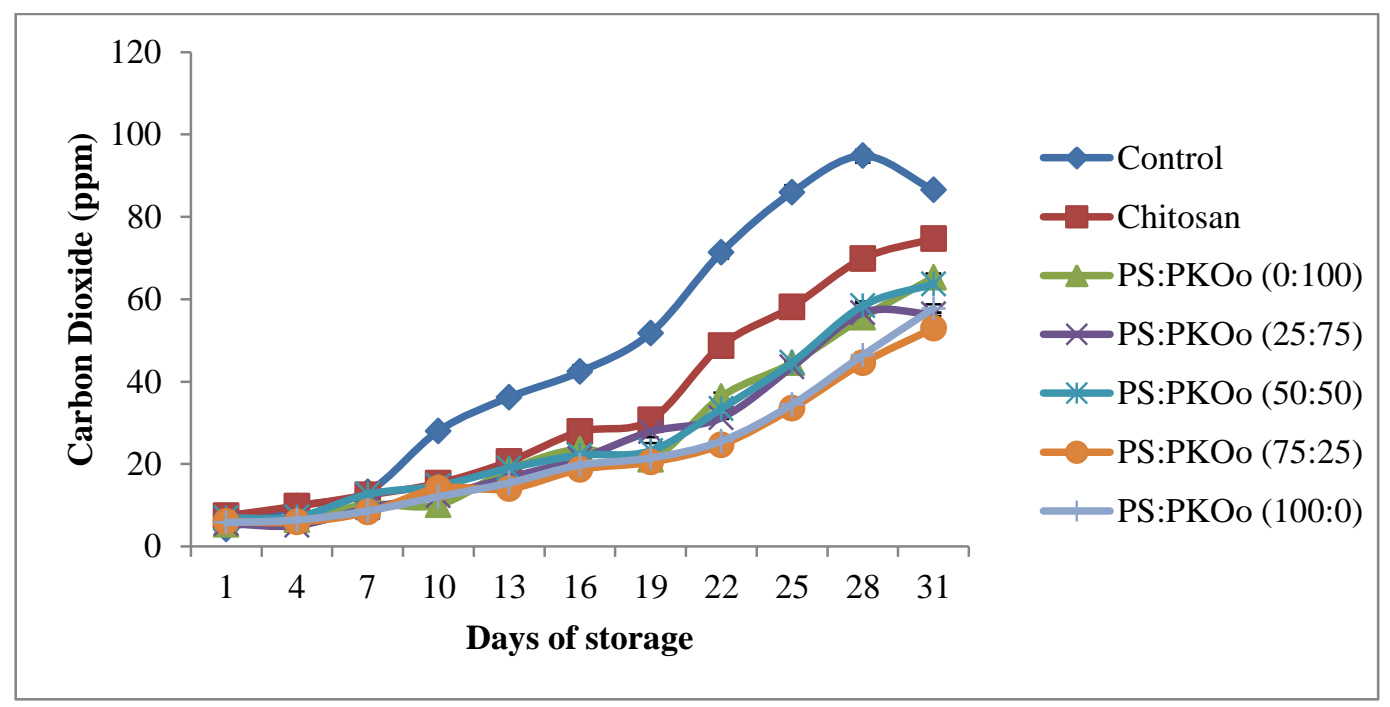

Figure 5. Carbon dioxide concentration of seedless guavas during storage at chilled temperature 
Application of lipid-chitosan coatings could control the production of carbon dioxide by the guava, with PS: PKOo (75:25) coating showing the lowest amount of carbon dioxide throughout the 31 days of storage. All the guavas showed increases in carbon dioxide concentration which agrees with the increase in the metabolic activity of guava. Carbon dioxide in internal tissue of fruits should be decreased to control the ripening process [18]. Carbon dioxide concentration is related to tissue senescence and cell breakdown [19]. The reduced rate of respiration in coated guava might be correlated with a delayed senescence and reduced susceptibility to decay. Hence, the chitosan-lipid coatings can be used to modify the internal atmosphere, thereby delaying the ripening of fruits.

As the amount of carbon dioxide is important to be decreased, the amount of oxygen surrounding the fruit should be maintained in order to control fruit ripening. The results of oxygen concentration (Figure 6) showed that all coatings had significantly prevented the decline of oxygen concentration surrounding the coated guavas $(\mathrm{P}<0.05)$ indicating a delay in fruit ripening as compared to the control. This indicates that coating acted as an oxygen barrier that limited the acceleration of aerobic respiration. According to Singh and Pal [14], the increase in oxygen concentration in storage atmosphere accelerated the loss of green colour in guava.

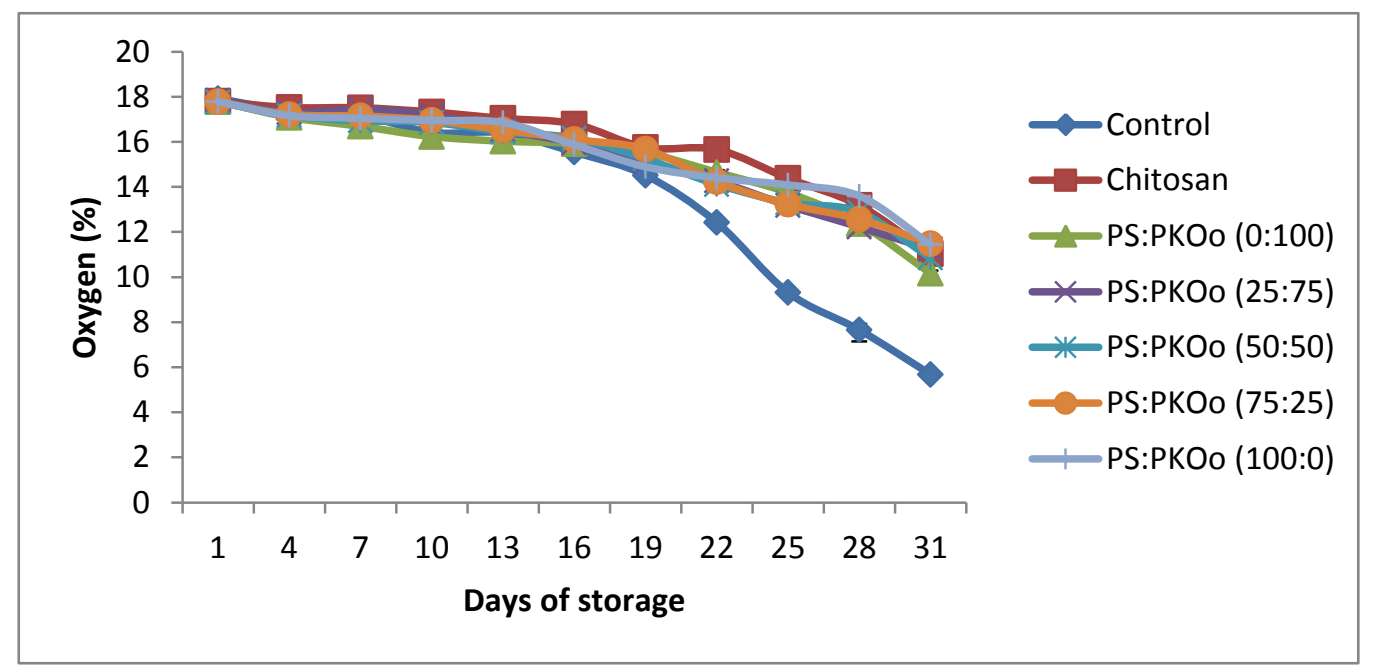

Figure 6. Oxygen concentration of seedless guavas during storage at chilled temperature

\section{Conclusion}

Application of edible lipid-chitosan coating was able to improve the quality and shelf-life of seedless guavas throughout 31 days of storage at chilled temperature. Results showed that the edible lipid-chitosan coating reduced the weight loss and increased the firmness retention. The coatings decreased ethylene and oxygen concentrations indicating a delay in fruit ripening as compared to the control. Application of lipid-chitosan coating showed beneficial effects on guava as it slowed the increases in carbon dioxide concentration of fruits. Overall, PSPKOo 75:25 was the best coating formulation as it showed good moisture and gas barrier properties. Hence, PS and PKOo showed potential to be used as cheap sources of edible coating.

Although the FFD in this study was found to have good moisture and gas barrier properties, chemical degradation of FFD could occur during storage. In order for this FFD to be used in commercial applications, future research is necessary to find methods to protect the FFD from degradation during storage. Incorporation of other types of lipids such as fatty acids or palm olein can be used as alternative lipids to improve FFD properties. Sensory evaluation can also be conducted to determine the perception of consumers towards the appearance and overall acceptability of coated fruits. 
Nurul Adilla et al: EFFECT OF EDIBLE LIPID-CHITOSAN FILM FORMING DISPERSION ON

POSTHARVEST LIFE OF GUAVA STORED AT CHILLED TEMPERATURE

\section{Acknowledgement}

We thank the Ministry of Higher Education of Malaysia for the financial support (600-RMI/ST/FRGS 5/3 Fst (31/2010) and Universiti Teknologi MARA for giving us the opportunity to conduct this research.

\section{References}

1. Zahedi, Y., Ghanbarzadeh, B. and Sedaghat, N. (2010). Physical properties of edible emulsified films based on pistachio globulin protein and fatty acids. Journal of Food Engineering, 100(1): $102-108$.

2. Gennadios, A., Weller, C. L. and C. H. and Gooding, C. H. (1994). Measurements errors in water vapour permeability of highly permeable, hydrophilic edible films, Journal of Food Engineering, 21: 395 - 409.

3. Hernandez, E. (1994). Edible coatings from lipids and resins. In J. M. Krochta, E. A. Baldwin and M. O. NisperosCarriedo (Ed.), Edible Coatings and Films to Improve Food Quality. Lancaster, Pennsylvania: Technomic Publishing Company, Inc. pp. 279 - 303.

4. Barbara, B., Donatella, P. and Alessandro, S. (2006). Development and application of polysaccharide - lipid edible coating to extend shelf life of dry bakery products. Journal of Food Engineering, 76: 280 - 290.

5. Chien, P. J., Sheu, F. and Yang, F. H. (2007). Effects of edible chitosan coating on quality and shelf life of sliced mango fruit. Journal of Food Engineering, 78: 225 - 229.

6. Kaplan, D. L., Mayer, J. M., Ball, D., McCassie, J., Allen, A. L. and Stenhouse, P. (1993). Fundamental of biodegradable polymer. In Ching, C., Kaplan D., and Thomas E. (eds.). Biodegradable Polymers and Packaging. Lancaster: Technomic Publishing. pp. $1-42$

7. Norizzah, A. R., Chong, C. L., Cheow, C. S. and Zaliha, O. (2004). Effects of chemical interesterification on physicochemical properties of palm stearin and palm kernel olein blends. Food Chemistry, 86: 229 - 235.

8. Vargas, M., Albors, A., Chiralt, A., and González-Martínez, C. (2009). Characterization of chitosan-oleic acid composite films. Food Hydrocolloids, 23: 536 - 547.

9. Vargas, M., Albors, A., Chiralt, A., and González-Martínez, C. (2006). Quality of cold-stored strawberries as affected by chitosan-oleic acid edible coatings. Postharvest Biology and Technology, 41: $164-171$.

10. Martínez-Romero, D., Alburquerque, N., Valverde, J. M., Guillèn, F., Castello, S., Valero, D. and Serrano, M. (2006). Postharvest sweet cherry quality and safety maintenance by Aloe vera treatment: a new edible coating. Postharvest Biology and Technology, 39: 93 - 100.

11. Abd. Rashid, N., Amin Zaki, E. N. and Mohd Som, H. Z. (2009). Application of water-based and lipid-based stearin wax coatings to improve the quality and shelf-life of seedless guavas (Psidium guajava L.). Paper presented at World Congress on oils \& fats and $28^{\text {th }}$ ISF Congress 2009. Sydney, Australia.

12. Maftoonazad, N. and Ramaswamy, H. S (2005). Postharvest shelf-life extension of avocados using methylcellulose-based coating. LWT Food Science and Technology, 38: 617 - 624.

13. Tanadu-Palmu, P. S. and Grosso, C. R. F. (2005). Effect of edible wheat gluten-based films and coatings on refrigerated strawberry (Fragariaananassa) quality. Postharvest Biology and Technology, 36: 199-208.

14. Singh, S. P., Pal, R. K. (2008). Response of climacteric-type guava (Psidiumguajava L.) to posthrvest treatment with 1-MCP. Postharvest Biology andTechnolology, 47: $307-314$.

15. Gonzalez-Aguilar, G. A., Tiznado-Hernandez, M. E., Zavaleta Gatica, R. and Martinez Tellez, M. A., (2004). Methyl jasmonate treatments reduce chilling injury and activate the defense response of guava fruits. Biochemical Biophysic Research Communinaction, 313: 694 - 701.

16. Morillon, V., Debeaufort, F., Blond, G., Capelle, M. and Voilley, A. (2002). Factors affecting the moisture permeability of lipid-based edible films: a review. Critical Review in Food Science and Nutrition, 42: 67 -89.

17. Yaman, O. and Bayoundurh, L. (2002). Effects of an edible coating and cold storage on shelf-life and quality of cherries. Journal of Food Engineering, 35: 146 - 150.

18. Nurul Hanani, M. Z., Halimahton Zahrah, M. S. and Zaibunnisa, A. H. (2012). Application of palm stearinchitosan edible coating on star fruits (Averrhoacarambola L.) Malaysian Journal of Analytical Sciences, 16(3): $325-334$.

19. Pastor, C., Sanchez-Gonzalez, L., Marcilla, A., Chiralt, A., Chafer, M. and Gonzalez-Martinez, C. (2011). Quality and safety of table grapes coated with hydroxypropylmethylcellulose edible coatings containing propolis extract. Postharvest Biology and Technology, 36: 69 - 75. 